\title{
Sistem Pendukung Keputusan Menentukan Lokasi Event PT. Mitra Panglima Sejahtera (MPS) Honda Pandeglang Menggunakan Metode Electre
}

\author{
Saefudin $^{1}$, Irwan $^{2}$ \\ ${ }^{1}$ Program Studi Sistem Informasi Fakultas Teknologi Informasi Universitas Serang Raya \\ ${ }^{2}$ Program Studi Teknik Informatika Fakultas Teknologi Informasi Universitas Serang Raya \\ Jalan Raya Serang-Cilegon KM. 5 Taman Drangong Serang, Banten \\ ${ }^{1}$ Saefudin12@gmail.com, \\ ${ }^{2}$ Irwan@yahoo.com
}

\begin{abstract}
Abstrak - PT. Mitra Panglima Sejahtera (MPS) Honda Pandeglang adalah sebuah perusahaan dalam bidang retail otomotif yang berkonsentrasi dalam bisnis penjualan kendaraan bermotor roda dua dengan cara pembayaran tunai ataupun kredit. Penentuan lokasi event merupakan salah satu kegiatan strategi pemasaran dan merupakan kegiatan yang penting terutama tercapainya target perusahaan. Dalam penentuan lokasi strategis untuk penentuan lokasi event, pihak penyelenggara yang biasa disebut event organizer (EO) sering kali mendapat kesulitan karena banyaknya kriteria yang harus dipertimbangkan untuk mencari lokasi yang baik. Kegagalan dalam menentukan lokasi strategis untuk kegiatan event akan merugikan perusahaan, sehingga memilih lokasi yang tepat adalah salah satu hal yang paling penting.

Metode penelitian yang digunakan yaitu metode observasi dan studi pustaka. Tahap perancangan 18ystem meliputi perancangan UML (Unified Modeling Language) dan perancangan antarmuka (user interface). Tahap pembuatan aplikasi menggunakan PHP dan mysql sebagai databasenya.

Tujuan akhir penelitian ini adalah membuat sebuah aplikasi 18ystem pendukung keputusan menentukan lokasi event PT. MPS Honda Pandeglang menggunakan metode Electre yang dapat memberikan kemudahan dalam merekomendasikan kepada pihak perusahaan informasi detail untuk lokasi event.
\end{abstract}

Kata Kunci: Electre, Sistem Pendukung Keputusan, Lokasi Event

\section{PENDAHULUAN}

PT. Mitra Panglima Sejahtera (MPS) Honda Pandeglang adalah sebuah perusahaan dalam bidang retail otomotif yang berkonsentrasi dalam bisnis penjualan kendaraan bermotor roda dua dengan cara pembayaran tunai ataupun kredit. PT MPS Honda mempunyai beberapa cabang dealer yang tersebar di wilayah Banten, seperti Serang, Cilegon, Pandeglang, Labuan, Panimbang, Rangkasbitung dan Cibaliung.

Penentuan lokasi event merupakan salah satu kegiatan strategi pemasaran dan merupakan kegiatan yang penting terutama tercapainya target perusahaan. Dalam penentuan lokasi strategis untuk penentuan lokasi event, pihak penyelenggara yang biasa disebut event organizer (EO) sering kali mendapat kesulitan karena banyaknya kriteria yang harus dipertimbangkan untuk mencari lokasi yang baik. Kegagalan dalam menentukan lokasi strategis untuk kegiatan event akan merugikan perusahaan, sehingga memilih lokasi yang tepat adalah salah satu hal yang paling penting.

Berdasarkan masalah diatas, maka perlu dibuatkan 18ystem pendukung keputusan (SPK) yang dapat membantu pihak penyelenggara dalam menentukan lokasi untuk kegiatan event dengan menggunakan metode Electre. Sehingga dapat membantu pihak penyelenggara event menentukan lokasi yang tepat.

\section{METODOLOGI PENELITIAN}

Metode yang di gunakan dalam penelitian ini adalah Metode Elimination Et Choix Traduisant La Realite (ELECTRE)

\subsection{Metode ELECTRE}

adalah suatu metode penentuan urutan (prioritas) dalam analisis multikriteria. Masalah pokoknya adalah kesederhanaan, 
Jurnal Sistem Informasi Volume.5 No.1, Maret 2018

kejelasan, kestabilan. Dugaan dan dominasi kriteria yang digunakan dalam metode Electre adalah penggunaan nilai hubungan outranking Methods.

Langkah yang dilakukan dalam penyelesaian masalah adalah sebagai berikut:

1. Normalisasi matriks keputusan.

2. Pembobotan pada matriks yang telah dinormalisasi.

3. Menentukan aggregate dominance matrix.

4. Eliminasi alternatif yang less favourable.

\subsection{Sistem Pendukung Keputusan}

Sistem pendukung keputusan adalah sekumpulan elemen yang saling berhubungan untuk membentuk suatu kesatuan dalam proses pemilihan berbagai alternatif tindakan guna menyelesaikan suatu masalah, sehingga masalah tersebut dapat diselesaikan secara efektif dan efisien. Kusrini (2007)

Tujuan dari Sistem Pendukung Keputusan adalah

2. Membantu manajer dalam pengambilan keputusan atas masalah semistruktur

3. Memberikan dukungan atas pertimbangan manajer dan bukannya dimaksudkan untuk menggantikan fungsi manajer

4. Peningkatan produktivitas

5. Berdaya saing

\section{HASIL DAN PEMBAHASAN}

\subsection{Analisa Input}

Dalam metode penelitian ini kriteria yang digunakan dalam adalah: Biaya, Kepadatan Penduduk, Akses Transportasi, Keamanan Lokasi dan Perijinan.

\subsection{Analisa Output}

Keluaran yang dihasilkan dari penelitian ini adalah diambil dari jumlah nilai akhir lokasi event yang memiliki nilai terbesar dibandingkan dengan nilai lokasi event lain. Hasil akhir yang dikeluarkan perhitungan akhir dari analisa Electre.

\subsection{Analisis Perhitungan Metode Electre}

Tahapan-tahapan perhitungan untuk menentukan nilai akhir

1. Menentukan alternatif dan kriteria :

Tabel 3.1. Alternatif

\begin{tabular}{|c|l|}
\hline Notasi & \multicolumn{1}{|c|}{ Alternatif } \\
\hline A1 & Alun-alun Pandeglang \\
\hline A2 & Pasar Pandeglang \\
\hline A3 & Pasar Cipeucang \\
\hline A4 & Pasar Menes \\
\hline A5 & Pasar Sabut \\
\hline
\end{tabular}

Tabel 3.2. Kriteria

\begin{tabular}{|c|l|}
\hline Notasi & \multicolumn{1}{|c|}{ Kriteria } \\
\hline K1 & Kriteria Biaya \\
\hline K2 & Kriteria Kepadatan Penduduk \\
\hline
\end{tabular}

e-ISSN: 2581-2181

\begin{tabular}{|l|l|}
\hline K3 & Kriteria Akses Transportasi \\
\hline K4 & Kriteria Keamanan Lokasi \\
\hline K5 & Kriteria Perijinan \\
\hline
\end{tabular}

2. Memberikan nilai rating kecocokan dan bobot prefensi dari tiap kriteria berikut ini :

Tabel 3.3. Kriteria

\begin{tabular}{|c|l|c|c|}
\hline Notasi & \multicolumn{1}{|c|}{ Kriteria } & Preferensi & Nilai \\
\hline K1 & Kriteria Biaya & 1 & $1,2,3$ \\
\hline K2 & Kriteria Kepadatan Penduduk & 3 & $1,2,3$ \\
\hline K3 & Kriteria Akses Transportasi & 3 & $1,2,3$ \\
\hline K4 & Kriteria Keamanan Lokasi & 1 & $1,2,3$ \\
\hline K5 & Kriteria Perijinan & 2 & $1,2,3$ \\
\hline
\end{tabular}

3. Memberikan nilai rating

Tabel 3.4. Rating Kecocokan dari Setiap Alternatif pada Setiap Kriteria

\begin{tabular}{|c|c|c|c|c|c|}
\hline \multirow{2}{*}{ Alternatif } & \multicolumn{5}{|c|}{ Kriteria } \\
\cline { 2 - 6 } & K1 & K2 & K3 & K4 & K5 \\
\hline A1 & 2 & 1 & 3 & 1 & 1 \\
\hline A2 & 2 & 1 & 2 & 3 & 1 \\
\hline A3 & 2 & 2 & 1 & 3 & 2 \\
\hline A4 & 1 & 1 & 1 & 2 & 3 \\
\hline A5 & 1 & 2 & 1 & 2 & 1 \\
\hline
\end{tabular}

\section{Melakukan Normalisasi Matrik Keputusan}

Tabel 3.5. Perhitungan Normalisasi Matriks Keputusan

\begin{tabular}{|c|c|c|c|c|c|c|c|c|c|c|c|c|c|c|c|}
\hline $\mathrm{Ai}$ & $\mathrm{Kj}$ & $\mathrm{Xij}$ & 1 & $\sqrt{ }$ & $\mathrm{Xi} 1^{2}$ & + & $\mathrm{Xi} 2^{2}$ & + & $\mathrm{Xi}^{2}$ & + & $\mathrm{Xi}^{2}$ & + & $\mathrm{Xi} 5^{2}$ & $=$ & Rij \\
\hline \multirow[t]{5}{*}{$\mathrm{A} 1$} & K1 & 2 & 1 & $\sqrt{ }$ & 4 & + & 4 & + & 4 & + & 1 & + & 1 & $=$ & 0.535 \\
\hline & $\mathrm{K} 2$ & 1 & 1 & $\sqrt{ }$ & 1 & + & 1 & + & 4 & + & 1 & + & 4 & $=$ & 0.302 \\
\hline & K3 & 3 & 7 & $\sqrt{ }$ & 9 & + & 4 & + & 1 & + & 1 & + & 1 & $=$ & 0.750 \\
\hline & K4 & 1 & 1 & $\sqrt{ }$ & 1 & + & 9 & + & 9 & + & 4 & + & 4 & $=$ & 0.192 \\
\hline & K5 & 1 & 7 & $\sqrt{ }$ & 1 & + & 1 & + & 4 & + & 9 & + & 1 & $=$ & 0.250 \\
\hline \multirow[t]{5}{*}{ A2 } & K1 & 2 & 1 & $\sqrt{ }$ & 4 & + & 4 & + & 4 & + & 1 & + & 1 & $=$ & 0.535 \\
\hline & K2 & 1 & 1 & $\sqrt{ }$ & 1 & + & 1 & + & 4 & + & 1 & + & 4 & $=$ & 0.302 \\
\hline & K3 & 2 & 1 & $\sqrt{ }$ & 9 & + & 4 & + & 1 & + & 1 & + & 1 & $=$ & 0.500 \\
\hline & K4 & 3 & 1 & $\sqrt{ }$ & 1 & + & 9 & + & 9 & + & 4 & + & 4 & $=$ & 0.577 \\
\hline & K5 & 1 & 1 & & 1 & + & 1 & + & 4 & + & 9 & + & 1 & $=$ & 0.250 \\
\hline \multirow[t]{5}{*}{ A3 } & K1 & 2 & 1 & $\sqrt{ }$ & 4 & + & 4 & + & 4 & + & 1 & + & 1 & $=$ & 0.535 \\
\hline & K2 & 2 & 1 & $\sqrt{ }$ & 1 & + & 1 & + & 4 & + & 1 & + & 4 & $=$ & 0.603 \\
\hline & K3 & 1 & 1 & $\sqrt{ }$ & 9 & + & 4 & + & 1 & + & 1 & + & 1 & $=$ & 0.250 \\
\hline & K4 & 3 & 1 & $\sqrt{ }$ & 1 & + & 9 & + & 9 & + & 4 & + & 4 & $=$ & 0.577 \\
\hline & K5 & 2 & 7 & $\sqrt{ }$ & 1 & + & 1 & + & 4 & + & 9 & + & 1 & $=$ & 0.500 \\
\hline \multirow[t]{5}{*}{ A4 } & K1 & 1 & 1 & $\sqrt{ }$ & 4 & + & 4 & + & 4 & + & 1 & + & 1 & $=$ & 0.267 \\
\hline & K2 & 1 & 1 & $\sqrt{ }$ & 1 & + & 1 & + & 4 & + & 1 & + & 4 & $=$ & 0.302 \\
\hline & K3 & 1 & 1 & $\sqrt{ }$ & 9 & + & 4 & + & 1 & + & 1 & + & 1 & $=$ & 0.250 \\
\hline & K4 & 2 & 1 & $\sqrt{ }$ & 1 & + & 9 & + & 9 & + & 4 & + & 4 & $=$ & 0.385 \\
\hline & K5 & 3 & 1 & $\sqrt{ }$ & 1 & + & 1 & + & 4 & + & 9 & + & 1 & $=$ & 0.750 \\
\hline \multirow[t]{5}{*}{ A5 } & K1 & 1 & 1 & $\sqrt{ }$ & 4 & + & 4 & + & 4 & + & 1 & + & 1 & $=$ & 0.267 \\
\hline & K2 & 2 & 1 & $\sqrt{1}$ & 1 & + & 1 & + & 4 & + & 1 & + & 4 & $=$ & 0.603 \\
\hline & K3 & 1 & 1 & $\sqrt{ }$ & 9 & + & 4 & + & 1 & + & 1 & + & 1 & $=$ & 0.250 \\
\hline & K4 & 2 & 1 & $\sqrt{ }$ & 1 & + & 9 & + & 9 & + & 4 & + & 4 & $=$ & 0.385 \\
\hline & K5 & 1 & 1 & $\sqrt{ }$ & 1 & + & 1 & + & 4 & + & 9 & + & 1 & $=$ & 0.250 \\
\hline
\end{tabular}


Dari perhitungan tabel diatas diperoleh tabel nomalisasi matriks keputusan sebagai berikut.

Tabel 3.6. Normalisasi Matriks Keputusan

\begin{tabular}{|c|c|c|c|c|c|}
\hline \multirow{2}{*}{ Alternatif } & \multicolumn{5}{|c|}{ Kriteria } \\
\cline { 2 - 6 } & K1 & K2 & K3 & K4 & K5 \\
\hline A1 & 0.535 & 0.302 & 0.750 & 0.192 & 0.250 \\
\hline A2 & 0.535 & 0.302 & 0.500 & 0.577 & 0.250 \\
\hline A3 & 0.535 & 0.603 & 0.250 & 0.577 & 0.500 \\
\hline A4 & 0.267 & 0.302 & 0.250 & 0.385 & 0.750 \\
\hline A5 & 0.267 & 0.603 & 0.250 & 0.385 & 0.250 \\
\hline
\end{tabular}

5. Pembobotan pada matriks yang telah dinormalisasi.

Setelah dinormalisasi, setiap kolom pada tabel normalisasi matriks keputusan dikalikan dengan bobotbobot $\left(\mathrm{w}_{\mathrm{j}}\right)$ yang ditentukan oleh pembuat keputusan. Sehingga, weighted normalized matrix adalah $\mathrm{V}=\mathrm{R} * \mathrm{~W}$. Berikut adalah tabel perhitungan perkalian antara tabel normalisasi matriks keputusan dan bobotnya.

Tabel 3.7. Perhitungan Pembobotan pada Matriks Ternormalisasi

\begin{tabular}{|c|c|c|c|c|c|c|}
\hline $\mathrm{Ai}$ & $\mathrm{Kj}$ & Rij & $*$ & $\mathrm{Wj}$ & $=$ & Vij \\
\hline \multirow{5}{*}{ A1 } & K1 & 0.535 & $*$ & 1 & $=$ & 0.535 \\
\hline & $\mathrm{K} 2$ & 0.302 & $*$ & 3 & $=$ & 0.905 \\
\hline & K3 & 0.750 & $*$ & 3 & $=$ & 2.250 \\
\hline & $\mathrm{K} 4$ & 0.192 & $*$ & 1 & $=$ & 0.192 \\
\hline & K5 & 0.250 & $*$ & 2 & $=$ & 0.500 \\
\hline \multirow{5}{*}{ A2 } & K1 & 0.535 & $*$ & 1 & $=$ & 0.535 \\
\hline & $\mathrm{K} 2$ & 0.302 & $*$ & 3 & $=$ & 0.905 \\
\hline & K3 & 0.500 & $*$ & 3 & $=$ & 1.500 \\
\hline & K4 & 0.577 & $*$ & 1 & $=$ & 0.577 \\
\hline & K5 & 0.250 & $*$ & 2 & $=$ & 0.500 \\
\hline \multirow{5}{*}{ A3 } & $\mathrm{K} 1$ & 0.535 & $*$ & 1 & $=$ & 0.535 \\
\hline & $\mathrm{K} 2$ & 0.603 & $*$ & 3 & $=$ & 1.809 \\
\hline & K3 & 0.250 & $*$ & 3 & $=$ & 0.750 \\
\hline & $\mathrm{K} 4$ & 0.577 & $*$ & 1 & $=$ & 0.577 \\
\hline & K5 & 0.500 & $*$ & 2 & $=$ & 1.000 \\
\hline \multirow{5}{*}{ A4 } & $\mathrm{K} 1$ & 0.267 & $*$ & 1 & $=$ & 0.267 \\
\hline & $\mathrm{K} 2$ & 0.302 & $*$ & 3 & $=$ & 0.905 \\
\hline & K3 & 0.250 & $*$ & 3 & $=$ & 0.750 \\
\hline & $\mathrm{K} 4$ & 0.385 & $*$ & 1 & $=$ & 0.385 \\
\hline & K5 & 0.750 & $*$ & 2 & $=$ & 1.500 \\
\hline \multirow{5}{*}{ A5 } & $\mathrm{K} 1$ & 0.267 & $*$ & 1 & $=$ & 0.267 \\
\hline & $\mathrm{K} 2$ & 0.603 & $*$ & 3 & $=$ & 1.809 \\
\hline & K3 & 0.250 & $*$ & 3 & $=$ & 0.750 \\
\hline & $\mathrm{K} 4$ & 0.385 & $*$ & 1 & $=$ & 0.385 \\
\hline & K5 & 0.250 & $*$ & 2 & $=$ & 0.500 \\
\hline
\end{tabular}

Dari perhitungan diatas diperoleh tabel pembobotan matriks ternomalisasi sebagai berikut.

Tabel 3.8 Pembobotan pada Matriks yang Telah Dinormalisasi

\begin{tabular}{|c|c|c|c|c|c|}
\hline \multirow{2}{*}{ Alternatif } & \multicolumn{5}{|c|}{ Kriteria } \\
\cline { 2 - 6 } & K1 & K2 & K3 & K4 & K5 \\
\hline A1 & 0.535 & 0.905 & 2.250 & 0.192 & 0.500 \\
\hline A2 & 0.535 & 0.905 & 1.500 & 0.577 & 0.500 \\
\hline A3 & 0.535 & 1.809 & 0.750 & 0.577 & 1.000 \\
\hline A4 & 0.267 & 0.905 & 0.750 & 0.385 & 1.500 \\
\hline A5 & 0.267 & 1.809 & 0.750 & 0.385 & 0.500 \\
\hline
\end{tabular}

6. Menentukan himpunan concordance dan disordance index.

Cara menentukan sebuah kriteria dalam suatu alternatif termasuk concordance adalah dengan mengimplementasikan rumus.

$$
C_{k l}=\left\{j, v_{k j} \geq v_{l j}\right\}, \text { untuk } j=1,2,3, \ldots, n .
$$

Tabel 3.9 Perhitungan Pencarian Himpunan Concordance dan nilai $C$

\begin{tabular}{|c|c|c|c|c|c|c|c|}
\hline $\mathrm{C}$ & $\mathrm{Xi}$ & 1 & 2 & 3 & 4 & 5 & Hasil \\
\hline \multirow[t]{4}{*}{ C11 } & 1 & 0.535 & 0.905 & 2.250 & 0.192 & 0.500 & \\
\hline & 1 & 0.535 & 0.905 & 2.250 & 0.192 & 0.500 & \\
\hline & Himp & 1 & 2 & 3 & 4 & 5 & $\{1,2,3,4,5\}$, \\
\hline & C & 1 & 3 & 3 & 1 & 2 & 10 \\
\hline \multirow[t]{4}{*}{$\mathrm{C} 12$} & 1 & 0.535 & 0.905 & 2.250 & 0.192 & 0.500 & \\
\hline & 2 & 0.535 & 0.905 & 1.500 & 0.577 & 0.500 & \\
\hline & Himp & 1 & 2 & 3 & & 5 & $\{1,2,3,5\}$, \\
\hline & $\mathrm{C}$ & 1 & 3 & 3 & & 2 & 9 \\
\hline \multirow[t]{4}{*}{$\mathrm{C} 13$} & 1 & 0.535 & 0.905 & 2.250 & 0.192 & 0.500 & \\
\hline & 3 & 0.535 & 1.809 & 0.750 & 0.577 & 1.000 & \\
\hline & Himp & 1 & & 3 & & & $\{1,3\}$, \\
\hline & $\overline{\mathrm{C}}$ & 1 & & 3 & & & 4 \\
\hline \multirow[t]{4}{*}{$\mathrm{C} 14$} & 1 & 0.535 & 0.905 & 2.250 & 0.192 & 0.500 & \\
\hline & 4 & 0.267 & 0.905 & 0.750 & 0.385 & 1.500 & \\
\hline & Himp & 1 & 2 & 3 & & & $\{1,2,3\}$, \\
\hline & $\mathrm{C}$ & 1 & 3 & 3 & & & 7 \\
\hline \multirow[t]{4}{*}{$\mathrm{C} 15$} & 1 & 0.535 & 0.905 & 2.250 & 0.192 & 0.500 & \\
\hline & 5 & 0.267 & 1.809 & 0.750 & 0.385 & 0.500 & \\
\hline & Himp & 1 & & 3 & & 5 & $\{1,3,5\}$, \\
\hline & $\mathrm{C}$ & 1 & & 3 & & 2 & 6 \\
\hline \multirow[t]{4}{*}{$\mathrm{C} 21$} & 2 & 0.535 & 0.905 & 1.500 & 0.577 & 0.500 & \\
\hline & 1 & 0.535 & 0.905 & 2.250 & 0.192 & 0.500 & \\
\hline & Himp & 1 & 2 & & 4 & 5 & $\{1,2,4,5\}$, \\
\hline & $\mathrm{C}$ & 1 & 3 & & 1 & 2 & 7 \\
\hline \multirow[t]{4}{*}{$\mathrm{C} 22$} & 2 & 0.535 & 0.905 & 1.500 & 0.577 & 0.500 & \\
\hline & 2 & 0.535 & 0.905 & 1.500 & 0.577 & 0.500 & \\
\hline & Himp & 1 & 2 & 3 & 4 & 5 & $\{1,2,3,4,5\}$, \\
\hline & $\mathrm{C}$ & 1 & 3 & 3 & 1 & 2 & 10 \\
\hline \multirow[t]{4}{*}{$\mathrm{C} 23$} & 2 & 0.535 & 0.905 & 1.500 & 0.577 & 0.500 & \\
\hline & 3 & 0.535 & 1.809 & 0.750 & 0.577 & 1.000 & \\
\hline & Himp & 1 & & 3 & 4 & & $\{1,3,4\}$, \\
\hline & C & 1 & & 3 & 1 & & 5 \\
\hline \multirow[t]{4}{*}{$\mathrm{C} 24$} & 2 & 0.535 & 0.905 & 1.500 & 0.577 & 0.500 & \\
\hline & 4 & 0.267 & 0.905 & 0.750 & 0.385 & 1.500 & \\
\hline & Himp & 1 & 2 & 3 & 4 & & $\{1,2,3,4\}$, \\
\hline & $\mathrm{C}$ & 1 & 3 & 3 & 1 & & 8 \\
\hline \multirow[t]{4}{*}{$\mathrm{C} 25$} & 2 & 0.535 & 0.905 & 1.500 & 0.577 & 0.500 & \\
\hline & 5 & 0.267 & 1.809 & 0.750 & 0.385 & 0.500 & \\
\hline & Himp & 1 & & 3 & 4 & 5 & $\{1,3,4,5\}$, \\
\hline & $\mathrm{C}$ & 1 & & 3 & 1 & 2 & 7 \\
\hline \multirow[t]{4}{*}{ C31 } & 3 & 0.535 & 1.809 & 0.750 & 0.577 & 1.000 & \\
\hline & 1 & 0.535 & 0.905 & 2.250 & 0.192 & 0.500 & \\
\hline & Himp & 1 & 2 & & 4 & 5 & $\{1,2,4,5\}$, \\
\hline & $\mathrm{C}$ & 1 & 3 & & 1 & 2 & 7 \\
\hline \multirow[t]{2}{*}{ C32 } & 3 & 0.535 & 1.809 & 0.750 & 0.577 & 1.000 & \\
\hline & 2 & 0.535 & 0.905 & 1.500 & 0.577 & 0.500 & \\
\hline
\end{tabular}


Jurnal Sistem Informasi Volume.5 No.1, Maret 2018

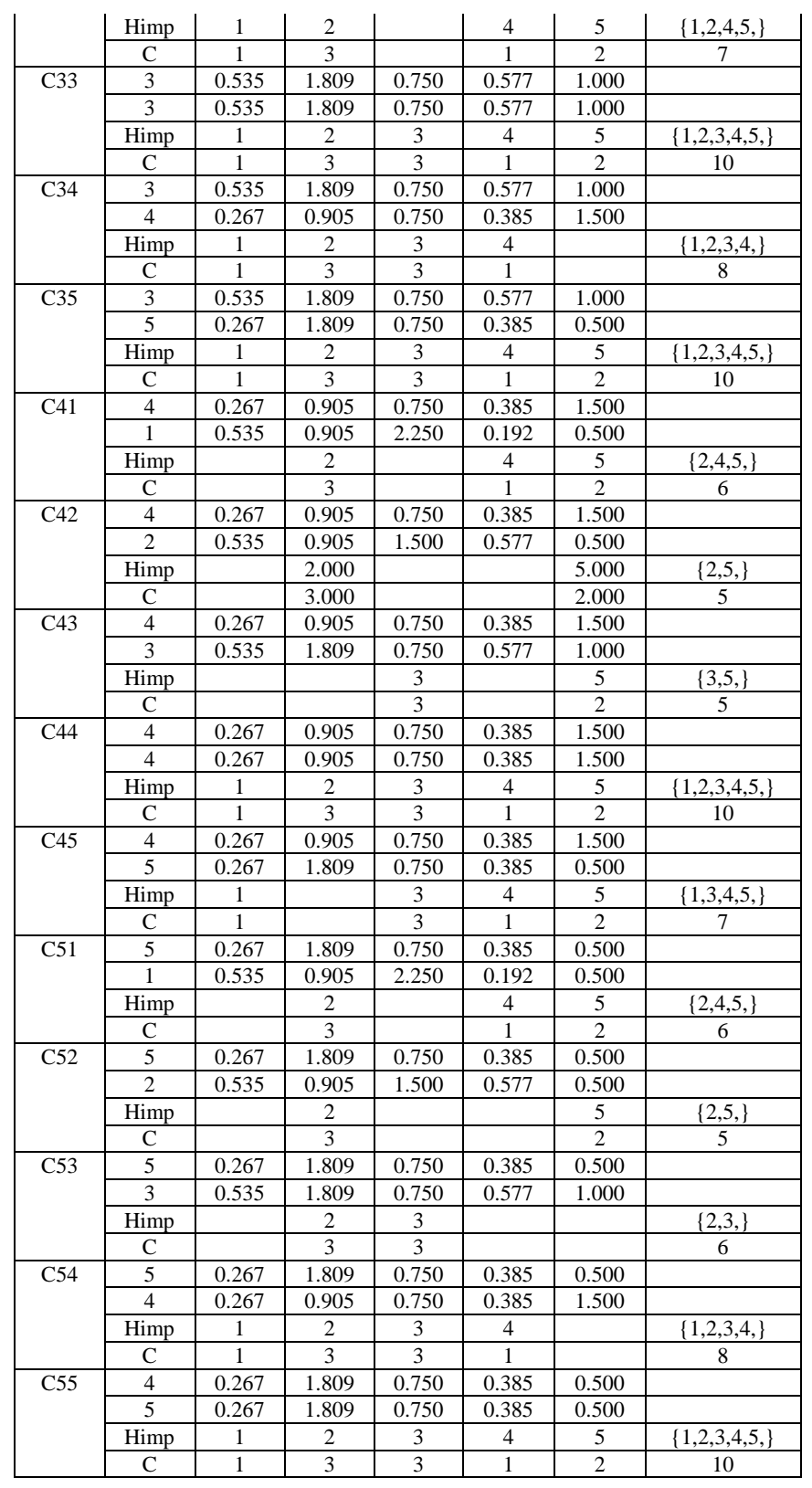

Dari perhitungan tabel diatas diperoleh himpunan concordance sebagai berikut.

Tabel 3.10. Himpunan Concordance

\begin{tabular}{|c|c|}
\hline $\mathrm{C}_{\mathrm{kl}}$ & Himpunan \\
\hline 12 & $\{1,2,3,5\}$, \\
\hline 13 & $\{1,3\}$, \\
\hline 14 & $\{1,2,3\}$, \\
\hline 15 & $\{1,3,5\}$, \\
\hline
\end{tabular}

p-ISSN: 2406-7768

e-ISSN: 2581-2181

\begin{tabular}{|c|c|}
21 & $\{1,2,4,5\}$, \\
\hline 23 & $\{1,3,4\}$, \\
\hline 24 & $\{1,2,3,4\}$, \\
\hline 25 & $\{1,3,4,5\}$, \\
31 & $\{1,2,4,5\}$, \\
\hline 32 & $\{1,2,4,5\}$, \\
\hline 34 & $\{1,2,3,4\}$, \\
\hline 35 & $\{1,2,3,4,5\}$, \\
41 & $\{2,4,5\}$, \\
\hline 42 & $\{2,5\}$, \\
\hline 43 & $\{3,5\}$, \\
\hline 45 & $\{1,3,4,5\}$, \\
51 & $\{2,4,5\}$, \\
\hline 52 & $\{2,5\}$, \\
\hline 53 & $\{2,3\}$, \\
\hline 54 & $\{1,2,3,4\}$, \\
\hline
\end{tabular}

Sebuah kriteria dalam suatu alternatif termasuk discordance adalah dengan mengimplementasikan rumus sebagai berikut:

$$
D_{k l}=\left\{j, v_{k j}<v_{l j}\right\}, \text { untuk } j=1,2,3, \ldots, n \text {. }
$$

Tabel 3.11. Perhitungan Pencarian Himpunan Discordance dan Nilai $D$

\begin{tabular}{|c|c|c|c|c|c|c|c|}
\hline $\mathrm{D}$ & $\mathrm{Xi}$ & 1 & 2 & 3 & 4 & 5 & Max \\
\hline \multirow[t]{6}{*}{ D11 } & 1 & 0.535 & 0.905 & 2.250 & 0.192 & 0.500 & \\
\hline & 1 & 0.535 & 0.905 & 2.250 & 0.192 & 0.500 & \\
\hline & Himpunan & & & & & & \{\} \\
\hline & Selisih & 0.000 & 0.000 & 0.000 & 0.000 & 0.000 & 0.000 \\
\hline & Selisih & & & & & & 0.000 \\
\hline & $\mathrm{D}$ & & & & & & 0.000 \\
\hline \multirow[t]{6}{*}{ D12 } & 1 & 0.535 & 0.905 & 2.250 & 0.192 & 0.500 & \\
\hline & 2 & 0.535 & 0.905 & 1.500 & 0.577 & 0.500 & \\
\hline & Himpunan & & & & 4 & & $\{4\}$, \\
\hline & Selisih & 0.000 & 0.000 & 0.750 & 0.385 & 0.000 & 0.750 \\
\hline & Selisih & & & & 0.385 & & 0.385 \\
\hline & $\mathrm{D}$ & & & & & & 0.513 \\
\hline \multirow[t]{6}{*}{ D13 } & 1 & 0.535 & 0.905 & 2.250 & 0.192 & 0.500 & \\
\hline & 3 & 0.535 & 1.809 & 0.750 & 0.577 & 1.000 & \\
\hline & Himpunan & & 2 & & 4 & 5 & $\{2,4,5\}$, \\
\hline & Selisih & 0.000 & 0.905 & 1.500 & 0.385 & 0.500 & 1.500 \\
\hline & Selisih & & 0.905 & & 0.385 & 0.500 & 0.905 \\
\hline & $\mathrm{D}$ & & & & & & 0.603 \\
\hline \multirow[t]{3}{*}{ D14 } & 1 & 0.535 & 0.905 & 2.250 & 0.192 & 0.500 & \\
\hline & 4 & 0.267 & 0.905 & 0.750 & 0.385 & 1.500 & \\
\hline & Himpunan & & & & 4 & 5 & $\{4,5\}$, \\
\hline
\end{tabular}


Jurnal Sistem Informasi Volume.5 No.1, Maret 2018

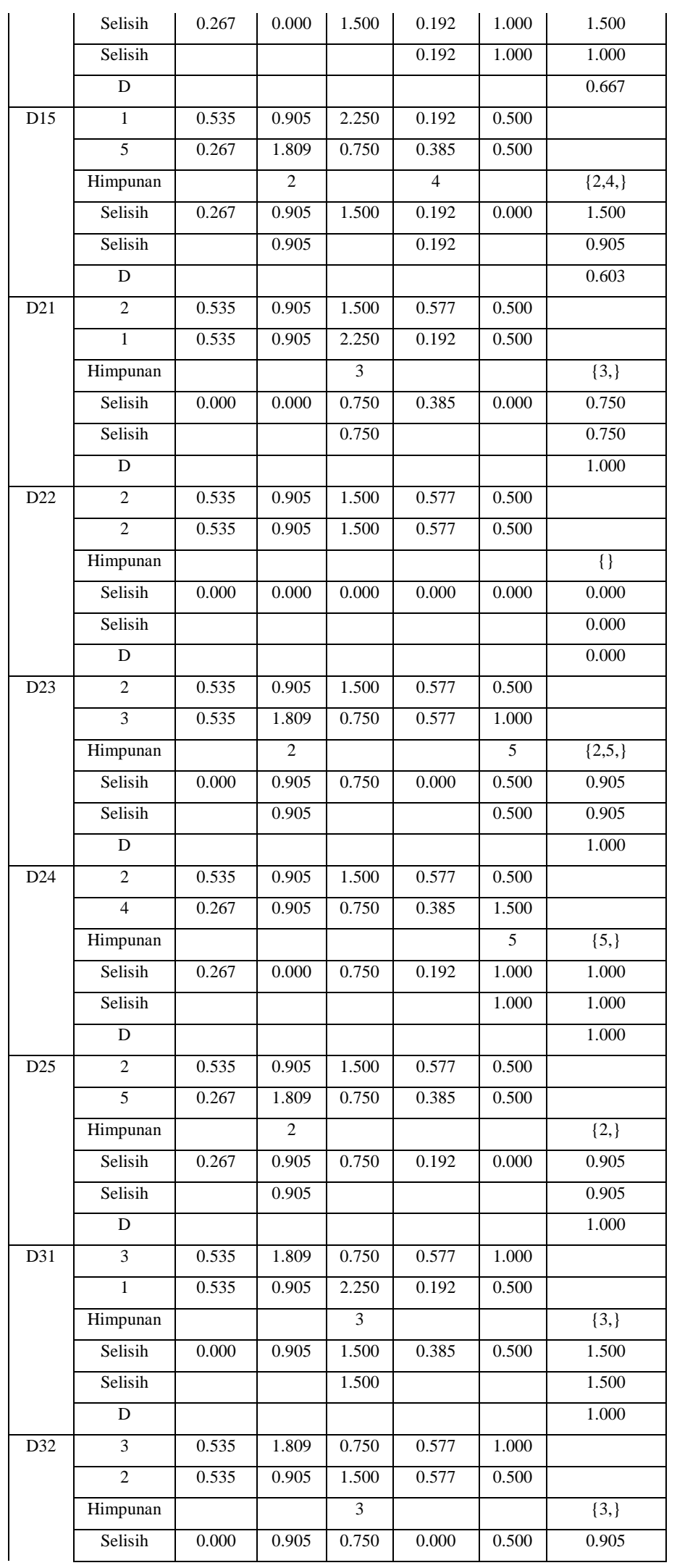

p-ISSN: 2406-7768

e-ISSN: 2581-2181

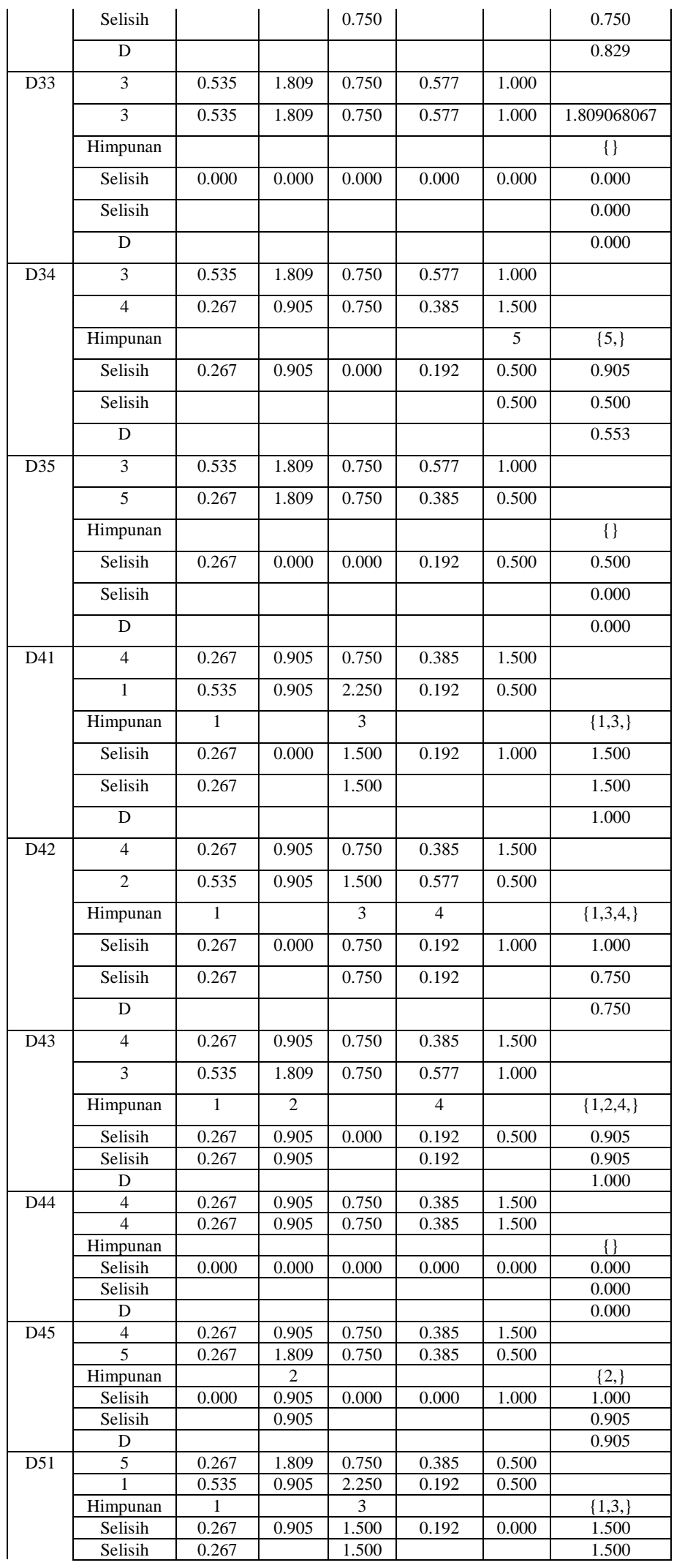


Jurnal Sistem Informasi Volume.5 No.1, Maret 2018

\begin{tabular}{|c|c|c|c|c|c|c|c|}
\hline & D & & & & & & 1.000 \\
\hline \multirow[t]{6}{*}{ D52 } & 5 & 0.267 & 1.809 & 0.750 & 0.385 & 0.500 & \\
\hline & 2 & 0.535 & 0.905 & 1.500 & 0.577 & 0.500 & \\
\hline & Himpunan & 1 & & 3 & 4 & & $\{1,3,4\}$, \\
\hline & Selisih & 0.267 & 0.905 & 0.750 & 0.192 & 0.000 & 0.905 \\
\hline & Selisih & 0.267 & & 0.750 & 0.192 & & 0.750 \\
\hline & $\mathrm{D}$ & & & & & & 0.829 \\
\hline \multirow[t]{6}{*}{ D53 } & 5 & 0.267 & 1.809 & 0.750 & 0.385 & 0.500 & \\
\hline & 3 & 0.535 & 1.809 & 0.750 & 0.577 & 1.000 & \\
\hline & Himpunan & 1 & & & 4 & 5 & $\{1,4,5\}$, \\
\hline & Selisih & 0.267 & 0.000 & 0.000 & 0.192 & 0.500 & 0.500 \\
\hline & Selisih & 0.267 & & & 0.192 & 0.500 & 0.500 \\
\hline & D & & & & & & 1.000 \\
\hline \multirow[t]{6}{*}{ D54 } & 5 & 0.267 & 1.809 & 0.750 & 0.385 & 0.500 & \\
\hline & 4 & 0.267 & 0.905 & 0.750 & 0.385 & 1.500 & \\
\hline & Himpunan & & & & & 5 & $\{5\}$, \\
\hline & Selisih & 0.000 & 0.905 & 0.000 & 0.000 & 1.000 & 1.000 \\
\hline & Selisih & & & & & 1.000 & 1.000 \\
\hline & $\mathrm{D}$ & & & & & & 1.000 \\
\hline \multirow[t]{6}{*}{ D55 } & 4 & 0.267 & 1.809 & 0.750 & 0.385 & 0.500 & \\
\hline & 5 & 0.267 & 1.809 & 0.750 & 0.385 & 0.500 & \\
\hline & Himpunan & & & & & & \{\} \\
\hline & Selisih & 0.000 & 0.000 & 0.000 & 0.000 & 0.000 & 0.000 \\
\hline & Selisih & & & & & & 0.000 \\
\hline & $\mathrm{D}$ & & & & & & 0.000 \\
\hline
\end{tabular}

Dari perhitungan tabel diatas diperolah tabel himpunan discordance sebagai berikut.

Tabel 3.12. Himpunan Discordance

\begin{tabular}{|c|c|}
\hline $\mathrm{D}_{\mathrm{kl}}$ & Himpunan \\
\hline 12 & $\{4\}$, \\
\hline 13 & $\{2,4,5\}$, \\
\hline 14 & $\{4,5\}$, \\
\hline 15 & $\{2,4\}$, \\
21 & $\{3\}$, \\
\hline 23 & $\{2,5\}$, \\
\hline 24 & $\{5\}$, \\
\hline 25 & $\{2\}$, \\
31 & $\{3\}$, \\
\hline 32 & $\{3\}$, \\
\hline 34 & $\{5\}$, \\
\hline 35 & \{\} \\
41 & $\{1,3\}$, \\
\hline 42 & $\{1,3,4\}$, \\
\hline 43 & $\{1,2,4\}$, \\
\hline 45 & $\{2\}$, \\
51 & $\{1,3\}$, \\
\hline 52 & $\{1,3,4\}$, \\
\hline 53 & $\{1,4,5\}$, \\
\hline 54 & $\{5\}$, \\
\hline
\end{tabular}

7. Menghitung matriks concordance dan disordance.

Untuk menentukan nilai dari elemen-elemen pada matriks concordance adalah dengan menjumlahkan bobot-bobot yang termasuk dalam subset concordance, secara matematisnya adalah:

$$
C_{k l}=\sum_{j \in C_{k l}} w_{j}
$$

Dari tabel perhitungan sebelumnya telah diperoleh tabel matriks concordance sebagai berikut.

Tabel 3.13. Matriks Concordance
p-ISSN: 2406-7768

e-ISSN: 2581-2181

\begin{tabular}{|c|c|c|c|c|c|}
\hline A & 1 & 2 & 3 & 4 & 5 \\
\hline 1 & - & 9 & 4 & 7 & 6 \\
\hline 2 & 7 & - & 5 & 8 & 7 \\
\hline 3 & 7 & 7 & - & 8 & 10 \\
\hline 4 & 6 & 5 & 5 & - & 7 \\
\hline 5 & 6 & 5 & 6 & 8 & - \\
\hline Total & \multicolumn{7}{|c|}{133} \\
\hline Threshold C & 6.65 \\
\hline
\end{tabular}

Untuk menentukan nilai dari elemen-elemen pada matriks discordance adalah dengan membagi maksimum selisih nilai kriteria yang termasuk dalam subset discordance dengan maksimum selisih nilai seluruh kriteria yang ada, secara matematisnya adalah:

$$
d_{k l}=\frac{\operatorname{Max}\left\{\left|v_{k j}-v_{i j}\right|\right\}_{j \in D_{k l}}}{\operatorname{Max}\left\{\left|v_{k j}-v_{l j}\right|\right\}_{\forall j}}
$$

Dari tabel perhitungan sebelumnya telah diperoleh tabel matriks discordance sebagai berikut.

Tabel 3.14. Matriks Discordance

\begin{tabular}{|c|c|c|c|c|c|}
\hline $\mathrm{A}$ & 1 & 2 & 3 & 4 & 5 \\
\hline 1 & - & 0.513 & 0.603 & 0.667 & 0.603 \\
\hline 2 & 1.000 & - & 1.000 & 1.000 & 1.000 \\
\hline 3 & 1.000 & 0.829 & - & 0.553 & 0.000 \\
\hline 4 & 1.000 & 0.750 & 1.000 & - & 0.905 \\
\hline 5 & 1.000 & 0.829 & 1.000 & 1.000 & - \\
\hline Total & \multicolumn{7}{|c|}{0.813 .252} \\
\hline $\begin{array}{c}\text { Threshold } \\
\text { D }\end{array}$ &
\end{tabular}

8. Menentukan matriks dominan concordance dan discordance.

Matrik dominan concordance dapat dibangun dengan bantuan nilai threshold, yaitu dengan cara membandingkan setiap nilai elemen matriks concordance dengan nilai threshold.

$$
C_{k l} \geq \underline{c}
$$

dengan nilai threshold ()), adalah:

$$
\underline{c}=\frac{\sum_{k=1}^{m} \sum_{l=1}^{m} c_{k l}}{m(m-1)}
$$

dan nilai setiap elemen matriks $\mathrm{F}$ sebagai matriks dominan concordance adalah dengan mengimplementasikan rumus sebagai berikut:

$$
f_{k l}=\left\{\begin{array}{l}
1, j i k a c_{k l} \geq \underline{c} \\
0, j i k a c_{k l}<\underline{c}
\end{array}\right.
$$

Tabel 3.15. Matriks Dominan Concordance 


\begin{tabular}{|c|c|c|c|c|c|}
1 & - & 1 & 0 & 1 & 0 \\
\hline 2 & 1 & - & 0 & 1 & 1 \\
\hline 3 & 1 & 1 & - & 1 & 1 \\
\hline 4 & 0 & 0 & 0 & - & 1 \\
\hline 5 & 0 & 0 & 0 & 1 & - \\
\hline
\end{tabular}

Untuk membangun tabel matriks dominan discordance juga menggunakan bantuan nilai threshold, yaitu dengan mengimplementasikan rumus berikut ini:

$$
\underline{d}=\frac{\sum_{k=1}^{m} \sum_{l=1}^{m} d_{k l}}{m(m-1)}
$$

dan nilai setiap elemen untuk tabel matriks $G$ sebagai matriks dominan discordance ditentukan dengan mengimplementasikan rumus sebagai berikut:

$$
g_{k l}=\left\{\begin{array}{l}
1, j i k a c_{k l} \geq \underline{d} \\
0, j i k a c_{k l}<\underline{d}
\end{array}\right.
$$

Tabel 3.16. Matriks Dominan Discordance

\begin{tabular}{|c|c|c|c|c|c|}
\hline A & 1 & 2 & 3 & 4 & 5 \\
\hline 1 & - & 0 & 0 & 0 & 0 \\
\hline 2 & 1 & - & 1 & 1 & 1 \\
\hline 3 & 1 & 1 & - & 0 & 0 \\
\hline 4 & 1 & 0 & 1 & - & 1 \\
\hline 5 & 1 & 1 & 1 & 1 & - \\
\hline
\end{tabular}

9. Menentukan aggregate dominance matrix.

Menentukan aggregate dominance matrix sebagai matriks E, yang setiap elemennya adalah perkalian elemen matriks $\mathrm{F}$ dengan elemen matriks $\mathrm{G}$.

$$
e_{k l}=f_{k l} x g_{k l}
$$

Tabel 3.19. Matriks Aggregate Dominance Matrix

\begin{tabular}{|c|c|c|c|c|c|c|}
\hline $\mathrm{A}$ & 1 & 2 & 3 & 4 & 5 & Jumlah \\
\hline 1 & - & 0 & 0 & 0 & 0 & 0 \\
\hline 2 & 1 & - & 0 & 1 & 1 & 3 \\
\hline 3 & 1 & 1 & - & 0 & 0 & 2 \\
\hline 4 & 0 & 0 & 0 & - & 1 & 1 \\
\hline 5 & 0 & 0 & 0 & 1 & - & 1 \\
\hline
\end{tabular}

10. Eliminasi alternatif yang les favourable

4. Hasil Analisa

Berdasarkan hasil analisa menggunkan metode Electre dengan mengambil 5 alternatif sebagai data sample, maka dapat direkomendasikan lokasi event terbaik adalah A2 yang mendominasi alternatif lainnya.

\subsection{Kesimpulan}

\section{KESIMPULAN}

Berdasarkan hasil penelitian dan pengujian sistem pendukung keputusan Menentukan Lokasi Event PT. Mitra Panglima Sejahtera (MPS) Honda Pandeglang Menggunakan Metode Electre, maka dapat diambil beberapa kesimpulan, yaitu :

1. Sistem penunjang keputusan untuk Menentukan Lokasi Event PT. Mitra Panglima Sejahtera (MPS) Honda Pandeglang Menggunakan Metode Electre dibuat menggunakan bahasa pemrograman PHP dan database mysql.

2. Dengan menerapkan metode Electre pada proses Menentukan Lokasi Event PT. Mitra Panglima Sejahtera (MPS) Honda Pandeglang lebih cepat dalam proses pengambilan keputusan yang bersifat objektif

\subsection{Saran}

Saran yang diajukan agar sistem pendukung keputusan Menentukan Lokasi Event PT. Mitra Panglima Sejahtera (MPS) Honda Pandeglang dapat digunakan dan berjalan dengan baik adalah :

1. Perlu adanya perbandingan aplikasi sistem pendukung keputusan penentuan lokasi event dengan aplikasi sistem pendukung keputusan penentuan lokasi event lainnya sebagai bagian dari peningkatan ataupun pengembangan.

2. Jika sistem pendukung keputusan penilaian kinerja pegawai sudah berjalan perlu adanya perawatan maupun perbaikan jika diperlukan sesuai kebutuhan

\section{REFERENSI}

[1]. Abner AP, dkk (2015). "Sistem Pendukung Keputusan Untuk Penerima Bantuan Pinjaman Samisake Dengan Metode Electre" (Studi Kasus: LKM Kelurahan Lingkar Timur Kota Bengkulu)." Jurnal Rekursif, Vol. 3 No. 1 Maret 2015, ISSN 2303-0755

[2]. Fauzi Wildan. (2016). "Sistem Pendukung Keputusan Penerima Bantuan Dana Rutilahu Dengan Menggunakan Metode Electre." Seminar Nasional Teknologi Informasi dan Komunikasi 2016 (SENTIKA 2016) ISSN: 2089-9815

[3]. Marlinda Linda (2016). "Sistem Pendukung Keputusan Pemilihan Tempat Wisata Yogyakarta Menggunakan Metode Elimination Et Choix Traduisant La Realita (ELECTRE)". Fakultas Teknik Universitas Muhammadiyah Jakarta ,Semnastek 2016. e-ISSN : 2460 $-8416$.

[4]. Setiawan Fahmi, dkk (2015). "Implementasi Metode Electre Pada Sistem Pendukung Keputusan SNMPTN Jalur Undangan". Kumpulan jurnaL Ilmu Komputer (KLIK) Volume 02, No.02. 5 ISSN: 2406-7857 
p-ISSN: 2406-7768

Jurnal Sistem Informasi Volume.5 No.1, Maret 2018

e-ISSN: 2581-2181 